\title{
Penyakit Yang Dapat Ditimbulkan Oleh Rokok
}

\author{
Checi Arum Septiani, Muhammad Ali Sodik
}

IIK STRADA INDONESIA

arumcheci@gmail.com, alisodik2012@gmail.com

\begin{abstract}
Abstrak
Rokok dapat kita temukan dengan mudah dimana saja. Mulai dari kaum milenial sampai kaum lansia tidak asing lagi dengan benda ini. Demikian pula dengan penduduk desa maupun kota. Bahkan oleh sebagian orang, rokok sudah menjadi kebutuhan hidup yang tidak bisa ditinggalkan begitu saja. Bisa dikatakan jika rokok adalah budaya sehari hari seseorang. Tidak sedikit orang berpendapat bahwa rokok merupakan benda yang dapat menghilangkan stres. Hal tersebut hanya efek dari nikotin yang sifatnya memberikan rasa tenang sesaat. Jika kita pelajari lebih dalam mengenai kandungan yang ada di dalam rokok, banyak dampak yang diberikan oleh rokok. Pada artikel kali ini saya akan mengkaji lebih dalam mengenai penyakit yang dapat ditimbulkan oleh rokok.
\end{abstract}

\section{Latar Belakang}

Perilaku merokok adalah aktivitas menghisap atau menghirup asap rokok dengan menggunakan pipa atau rokok yang dilakukan secara menetap dan terbentuk melalui empat tahap, yaitu: tahap preparation, initiation, becoming a smoker, dan maintenance of smoking (Maman, 2009).

Merokok adalah kebiasaan bodoh yang dapat membunuh diri sendiri dan tentu saja tidak ada yang bisa dipuji dari kebiasaan tersebut. Merokok membuat seseorang menjadi pucat, tampak tidak sehat dan keriput. Sesungguhnya seluruh perokok dewasa memulai kebiasaan mereka sejak usia remaja saat - saat mereka masih terlalu mudah untuk memikirkan konsekuensi jangka panjang dari merokok (Lovastatin, 2007).

Timbulnya kebiasan merokok ini biasanya diawali dari melihat orang sekitarnya merokok. Banyak anak-anak menganggap bahwa dengan merokok akan menjadi lebih dewasa. Ada pula yang merasa dengan merokok akan menimbulkan ketenangan, terlepas dari rasa takut dan gelisah (Aqib, 2011).

\section{Kasus / Masalah}

Merokok merupakan salah satu masalah yang sulit di pecahkan. Apalagi sudah menjadi masalah nasional, dan bahkan internasional. Hal ini menjadi sulit karena berkaitan dengan banyak faktor yang saling memicu, sehingga seolah-olah sudah menjadi lingkaran setan. Di tinjau dari segi kesehatan, merokok harus di hentikan karena menyebabkan kanker di penyumbatan pembuluh darah yang mengakibatkan kematian.

\section{Tinjauan Pustaka}

\subsection{Pengertian Rokok}

Rokok adalah lintingan atau gulungan tembakau yang digulung / dibungkus dengan kertas, daun, atau kulit jagung, sebesar kelingking dengan panjang 8-10 cm, biasanya dihisap 
seseorang setelah dibakar ujungnya.

Rokok merupakan pabrik bahan kimia berbahaya. Hanya dengan membakar dan menghisap sebatang rokok saja, dapat diproduksi lebih dari 4000 jenis bahan kimia. 400 diantaranya beracun dan 40 diantaranya bisa berakumulasi dalam tubuh dan dapat menyebabkan kanker. Rokok juga termasuk zat adiktif karena dapat menyebabkan adiksi (ketagihan) dan dependensi (ketergantungan) bagi orang yang menghisapnya. Dengan kata lain, rokok termasuk golongan NAPZA (Narkotika, Psikotropika, Alkohol, dan Zat Adiktif).

2.2 Bahan-Bahan Rokok yang Berbahaya Bagi Kesehatan

\section{a. Nikotin}

Nikotin memiliki efek candu seperti opium dan morfin. Nikotin berfungsi sebagai perantara dalam sistem saraf otak yang menyebabkan berbagai reaksi biokimia, termasuk efek menyenangkan dan menenangkan.

\section{b. Karbon monoksida $(\mathrm{CO})$}

Salah satu kandungan rokok yang merupakan gas beracun adalah karbon monoksida. Senyawa yang satu ini merupakan gas yang tidak memiliki rasa dan bau. Jika terhirup terlalu banyak, sel-sel darah merah akan lebih banyak berikatan dengan karbon monoksida dibanding dengan oksigen. Akibatnya fungsi otot dan jantung akan menurun. Hal ini akan menyebabkan kelelahan, lemas, dan pusing.

c. Tar

Timbunan tar berisiko tinggi menyebabkan penyakit pada paruparu, seperti kanker paru-paru dan
emfisema.Tidak hanya itu, tar akan masuk ke peredaran darah dan meningkatkan risiko terjadinya diabetes, penyakit jantung, hingga gangguan kesuburan. Tar dapat terlihat melalui noda kuning yang tertinggal di gigi dan jari. Karena tar masuk secara langsung ke mulut, zat berbahaya ini juga dapat mengakibatkan masalah gusi dan kanker mulut.

d. Hidrogen sianida

Efek dari senyawa ini dapat melemahkan paru-paru, menyebabkan kelelahan, sakit kepala, dan mual.

\section{e. Benzena}

Benzena merupakan residu dari pembakaran rokok. Paparan benzena jangka panjang (setahun atau lebih), dapat menurunkan jumlah sel darah merah dan merusak sumsum tulang, sehingga meningkatkan risiko terjadinya anemia dan perdarahan.

\section{f. Formaldehid}

Formaldehida merupakan residu dari pembakaran rokok. Dalam jangka pendek, formaldehida mengakibatkan iritasi pada mata, hidung, dan tenggorokan. Dalam jangka panjang, formaldehida dapat meningkatkan risiko kanker nasofaring.

\section{g. Kadmium}

Sekitar 40-60 persen dari kadmium yang terdapat dalam asap rokok, terserap masuk ke paru-paru saat merokok. Kadar kadmium yang tinggi dalam tubuh dapat menimbulkan gangguan sensorik, muntah, diare, kejang, kram otot, 
gagal ginjal, dan meningkatkan risiko kanker.

h. Arsenik

Arsenik merupakan golongan pertama karsinogen. Paparan terhadap arsenik tingkat tinggi dapat meningkatkan risiko terjadinya kanker kulit, kanker paru-paru, kanker saluran kemih, kanker ginjal, dan kanker hati.

\section{i. Amonia}

Amonia merupakan gas beracun, tidak berwarna, namun berbau tajam. Pada industri rokok, amonia digunakan untuk meningkatkan dampak candu nikotin.

\section{Pembahasan}

Penyakit yang dapat timbul karena rokok :

a. Caries

Rokok mempengaruhi keseimbangan kimiawi dalam mulut membentuk plak yang berlebihan, membuat gigi menjadi kuning dan terjadinya caries, perokok berisiko kehilangan gigi mereka 1,5 kali lipat.

\section{b. Emfisema}

Emfisema yaitu pelebaran dan rusaknya kantong udara pada paru-paru yang menurunkan kapasitas paru untuk menghisap oksigen dan melepaskan karbondioksida. Pada kasus yang parah digunakan Tracheotomy untuk membantu pernafasan pasien. Ibarat suatu sayatan untuk lubang ventilasi pada tenggorokan sebagai jalan masuk udara ke dalam paruparu. Pada kasus Bronkhitis kronis terjadi penumpukan muncus sehingga mengakibatkan batuk yang terasa nyeri dan kesulitan bernafas. c. Kanker paru - paru dan jantung

Pemakaian tembakau adalah salah satu faktor resiko terbesar untuk penyakit ini. Telah ditetapkan bahwa asap rokok mengandung lebih dari 40 macam zat racun. Kemungkinan timbulnya kanker paru dan jantung pada perokok 22 kali lebih besar daripada yang tidak merokok.

\section{d. Penyakit jantung}

Penyakit kardiovaskuler yang menyangkut pemakaian tembakau di Negara-negara maju membunuh lebih dari 600.000 orang setiap tahun. Rokok menyebabkan jantung berdenyut lebih cepat, menaikkkan tekanan darah dan meningkatkan resiko terjadinya hipertensi dan penyumbatan arteri yang akhirnya menyebabkan serangan jantung dan stroke.

e. Kerusakan paru

Selain kanker paru dan jantung merokok dapat pula menyebabkan batuk.

Dikarenakan rusaknya kantung udara pada paru yang menurunkan kapasitas paru dan oksigen untuk melepas oksigen. Bila keadaan ini belanjut akan terjadi penumpukan lendir sehingga mengakibatkan batuk yang tersa nyeri dan kesulitan bernafas.

f. Kanker mulut

Dilansir dari National Health Service UK, penyakit kanker mulut umum terjadi akibat pengonsumsian alkohol dan rokok. Rokok memiliki kandungan tembakau yang terdapat kandungan bahan kimia di dalamnya dan berisiko merusak DNA dalam sel yang meningkatkan risiko penyakit kanker.

\section{g. Gangguan Lambung}

Dilansir dari Everyday Health, kebiasaan merokok dengan gangguan lambung berkaitan erat. Ada beberapa alasan yang menyebabkan perokok rentan alami 
gangguan lambung, seperti sphincter esofagus pada bagian bawah yang melemah akibat kandungan nikotin dan kebiasaan merokok dapat memproduksi asam lambung lebih banyak.

\section{h. Kanker kulit}

Merokok dapat tingkatkan risiko penuaan dini. Kebiasaan merokok dapat menyebabkan gangguan kesehatan, seperti psoriasis. Psoriasis umumnya disebabkan oleh adanya gangguan autoimun. Jika kamu merokok, maka risiko terkena psoriasis menjadi lebih tinggi. Dilansir dari Fox News, kebiasaan merokok juga meningkatkan risiko mengalami kanker kulit. Tidak ada salahnya jaga kesehatan kulit dengan mengonsumsi air putih yang cukup dan hindari merokok.

\section{i. Tingkat kesuburan}

Kebiasaan merokok dan mengganggu tingkat kesuburan seseorang. Pada pria, kebiasaan merokok dapat meningkatkan risiko impotensi, mengurangi produksi sperma, dan kanker testis. Tidak hanya pada pria, kebiasaan merokok yang dilakukan wanita juga dapat sebabkan ketidaksuburan dan risiko kanker serviks. Kebiasaan merokok membuat sistem imun tubuh melemah dan mengurangi kemampuan tubuh untuk melawan infeksi HPV yang menjadi penyebab kanker serviks pada wanita.

\section{Kesimpulan}

Tidak sedikit orang yang memiliki kebiasaan merokok. Sebagian orang berpendapat bahwa merokok adalah kebutuhan sehari-hari. Tidak hanya di Indonesia, bahkan Internasional merokok menjadi salah satu masalah yang sulit dipecahkan.
Di dalam rokok terdapat zat seperti, nikotin, tar, karbon monoksida, hidrogen sianida, formaldehid, dan masih banyak zat berbahaya lainnya. Hal ini mengakibatkan rokok dapat menimbulkan penyakit yang berbahaya bahkan kematian. Terdapat sekitar 5000 senyawa berbeda dan sebagian bersifat racun bagi tubuh. Kandungan rokok yang bersifat racun tersebut berpotensi merusak sel-sel tubuh. Selain itu, senyawa dalam asap rokok juga bersifat karsinogenik alias memicu kanker. Di dalam rokok, terdapat 250 jenis zat beracun dan 70 jenis zat yang diketahui bersifat karsinogenik. Penyakit yang dapat timbul karena rokok sangat serius, seperti kanker, caries, penyakit jantung, gangguan paru-paru, hingga menyebabkan berkurangnya tingkat kesuburan.

Oleh karena itu, ada baiknya kita menjauhi rokok agar terhindar dari penyakit berbahaya akibat rokok. Jika Anda termasuk kedalam golongan orang perokok aktif berat, maka mulailah dari mengurangi porsi rokok Anda. Dengan demikian, tubuh akan menjadi bugar dan sehat.

\section{Daftar Pustaka}

Sodik, M. A. (2018). Merokok \& Bahayanya.

Setyani, A. T., \& Sodik, M. A. (2018). Pengaruh Merokok Bagi Remaja Terhadap Perilaku dan Pergaulan Seharihari.

Sodik, M. A., \& Setyani, A. T. (2018). Effect of Smoking For Teens Against Behavior and Social Interaction.

Sodik, M. A., \& Nzilibili, S. M. M. (2017). The Role Of Health Promotion And Family Support With Attitude Of Couples Childbearing Age In Following Family Planning Program In Health. 
Journal of Global Research in Public Health, 2(2), 82-89.

Amarin, Y. Journal Family Support as a Determinant Safety Riding Student Behavior in SMKN 2 Kediri. Indian Journal of Physioterapy and Occupatiol Therapy.

Gagan. 2017. Pengertian Merokok Dan Akibatnya.

https://dinkes.bantenprov.go.id/read/berita/ 488/PENGERTIAN-MEROKOK-DANAKIBATNYA.html . 1 Februari 2021 (09.26)

Adrian, Kevin. 2019. 9 Kandungan Rokok Yang Berefek Mengerikan Untuk Tubuh. https://www.alodokter.com/9kandungan-rokok-yang-berefekmengerikan-untuk-tubuh . 1 Februari 2021 (10.46)

Florencia, Gabriella. 2020. 5 Penyakit Ini Mengintai Perokok Aktif. https://www.halodoc.com/artikel/penyakitini-mengintai-perokok-aktif . 1 Februari 2021 (12.00) 